\title{
Evaluation of Lyme Disease in a Health Worker, and Review of the Literature
}

\author{
Fulya Bayındır Bilman, Mevliye Yetik \\ Department of Medical Microbiology, İzmir Menemen State Hospital, Izmir, Turkey \\ Email: f_bilman@hotmail.com
}

Received 9 April 2016; accepted 25 April 2016; published 29 April 2016

Copyright (C) 2016 by authors and OALib.

This work is licensed under the Creative Commons Attribution International License (CC BY). http://creativecommons.org/licenses/by/4.0/

(c) (i) Open Access

\begin{abstract}
Lyme disease (LD) is a multisystemic zoonotic infection disease that occurs in the consequence of contamination of Borrelia type of spirochetes that ticks carry after they have bitten. Typical clinic findings are on the skin and in joints. In this paper, the study on heavy joint pain having suddenly been added to the profile and on limitation of movement, and the process of getting the diagnosis of LD were probed in the patient with lesions on her skin that occurred three months ago. The case not having reported a history of being bitten by ticks and who was a health professional was female patient of 41 years of age. In her examination, a large number of lesions similar to fly bites were seen on the skin in the periphery of extremities, and the patient, whose routine hematologic and biochemical examinations were within normal limits, was determined to be Borrelia IgM positive and Borrelia IgG negative in the enzyme-linked immunosorbent assay (ELISA) tests performed from peripheric blood. Through these findings, cutaneous lesions and arthralgia were thought to be related to Borrelia infection that developed after the tick bite that took place months ago and was not realized. The patient was treated with doxycycline $(100 \mathrm{mg} / \mathrm{day}, 30$ days $)$ and prednisolone (16 mg/day, 30 days, reducing the dose). As a supplementary treatment, vitamin $D$ was administered by way of IM as a support. Arthralgia and joint involvement started to recover the second day. Lesions partly regresses in three days after the treatment started. LD cases must be considered in the differential diagnosis of infectious diseases that start with unexplained arthralgia at the beginning and suspicious lesions on the skin, and the case is probed by scanning literature over these concepts.
\end{abstract}

\section{Keywords}

Lyme Disease, Borrelia burgdorferi

Subject Areas: Infectious Diseases

\section{Introduction}

Lyme disease (LD) factor, caused by Borrelia burgdorferi type of spirochete, was first isolated from Ixodes 
dammini type of ticks by Dr. Willy Burgdorferi in the USA in 1982 [1]. Borrelia type of bacteria has loose convolutions in $0.2-0.5 \mu \mathrm{m}$ dimension, in 3 - $20 \mu \mathrm{m}$ length and in 3 - 10 number. The potential vector of these bacteria is Ixodes type of ticks. Borrelia types that cause LD have been classified as B. burgdorferi sensu lato, Borrelia garini and Borrelia afzelii since 1992 [2]-[4]. B. burgdorferisensu lato/strico genomic types involving mostly the joints and nervous system are reported to be LD factor in North America [5]. In Europe and Asia, $B$. garini and B. afzelii genomic types are seen to be LD factor. While B. garini emerges with meningopolyneurit findings, B. afzelii most often causes chronic profiles such as arthritis and skin lesions (acrodermatitis chronic athrophans) [6]. In LD, rarely encountered in our country, skin involvement is often seen after a 3 - 32 day incubation period [7].

Whereas over 12.000 cases were seen in the USA in 1995, the number of cases made an accurate diagnosis was 25,000 in 2014 [8]. The most common cases are male children at the age of 5 - 9 in this continent. This age group is followed by the cases at the age of $45-50$. LD is mostly seen in summers and less frequently in autumns. According to the data of CDC, it is erythema migrans (EM) that is seen in $70 \%$ of 154,405 cases and that is the most common symptom among all symptoms. Arthritis was found in $31 \%$ of the cases. Bell's palsy was found in $9 \%$, and meningitis and cardiac findings were found in $1 \%$ of the cases. Most of the patients are the children and young adults with the history of being in woody areas in their anamneses [8].

This disease can be defined in three phases according to its clinical findings [9]. In the first phase skin lesions are seen that develop in 3 - 30 days and that are known as EM. EM is found in 70\% - 80\% of the cases [10]-[12]. In the second phase, there can be fever, adenopathy, cold, neurologic and cardiac findings, ambulant arthralgia and oligoarticular arthritis. In the third phase, severe headaches and arthralgia, additional EM rashes, findings such as chronic arthritis involving the knee joint in which pain and swelling is marked, facial/Bell palsy, rarely myocarditis or subacute encephalopathy can be detected as late term findings. EM generally starts as a red macule or papule in the proximal parts of extremities or on the body. It generally expands enlarging from the center to the sides and its diameter can reach up to $50 \mathrm{~cm}$ [12]. Skin lesions generally disappear in 3 - 4 weeks [10]. Temperature increase, paresthesias, itching, pain happen in the lesion location. There can be symptoms such as fatigue, weakness, trembling, fever, headache, myalgia, and arthralgia. Seven days on the average pass for the lesion to occur after the ticks bite. Yet, EM is not found in $20 \%-30 \%$ of the cases. The second skin lesion is "Acrodermatitis chronic atrophica" and is characterized with blue-red color change [10]. Encephalopathy can very rarely develop years after. Pericardial effusion, cardiomyopathy and atrioventricular block can emerge as cardiovascular system findings [12]. Musculoskeletal system findings generally start 5 - 6 weeks later. It causes mono or oligoarticluar involvement with sudden onset and ambulant characteristic. Knee joint is the most frequently involved joint [13]. Intermittent swelling and pain can be found in the joint. Conjunctivitis, keratitis, uveitis, retinitis, and optic neuritis can be followed [14]. Findings can be seen such as the height of alanin transaminase (ALT), aspartat transaminase (AST) and bilirubin levels depending on liver involvement. Its diagnosis is hard. If an unnoticed tick bite is in question, the diagnosis can generally be disregarded easily provided that a serious physical examination is not performed. Determination of antibodies is important with serologic tests (enzyme immunoassay and western immunoblot) in suspicious cases. ELISA susceptibility alone is 89\% and specificity is $72 \%$ [15]. Also, wrong negative serologic results are encountered in the acute phase. The response of the antibody hosting $B$. burgdorferi slowly develops and serology is positive only half of the patients with early-phase LH. After EM starts, IgM and IgG antibodies appear in 2 - 4 and 4 - 6 weeks, respectively [16]. Serological tests are useful for confirming exposure to B. burgdorferi in all subsequent stages of Lyme disease. Antibody levels remain elevated for months to years. The determination of bacteria with polymerase chain reaction (PCR) in synovial liquid is $75 \%$ - $85 \%$ susceptible [17]. Although the golden standard in diagnosis is culture, special Barbour-Stoenna-Kelly medium is needed and is hard to use because B. burgdorferi reproduces slowly [18]. In the biopsies made from the cases with EM, spirochetes can be seen in papillary dermis with Warthin Starry silver paint [19]. Perivascular mononuclear infiltrate is followed histopathologically at surface and deep dermis layer.

In differential diagnosis, myopericardite, tularaemia, insect bites, Bell paralysis, acute rheumatic fever, Rocky Mountains Spotted Fever, streptococcal cellulites, eczema, meningitis, rheumatoid arthritis must be considered [9]. The most important criterium is the course of the lesion among EM and nonspecific arthropod bites. Reaction develops just after the bite caused by an uncertain arthropod and recovers in a few days without treatment through antibiotics. EM emerges after a latent period following the bite, lasts long and does not recover spontaneously [10]. The first option is doxycycline and amoxicilline in the treatment of LD that can be completely 
cured when diagnosed at an early phase [20].

It takes 36 - 48 hours for Borrelia species to increase in numbers in the ticks bowel tissue and to move to salivary glands [21]. Therefore, a single shot $200 \mathrm{mg}$ doxycycline is highly protective in two days after ticks bite.

There is no evidence that LD is transmitted from person to person. Yet, Lyme patients taking antibiotics cannot be donors, because bacteria are shown to be alive in the blood frozen for donation [8]. Also domestic animals suchlike dogs and cats can bring the bacteria to home through the ticks that they carry [22] [23].

\section{Case Report}

Female patient at the age of 41, health professional, applied to emergency service with the complaints of sudden, severe pain and movement restriction in knee and cervical joints and skin lesions existing for three months. During the physical examination, lesions belonging to two months ago on the legs and arms of the patients and estimated to be caused by fly bite, according to the patient, attracted attention. Routine examinations were required from the patient. Her vital findings were noted to be $38^{\circ} \mathrm{C}$ body temperature, $120 / 80 \mathrm{mmHg}$ blood pressure, 90/min. pulse, 22/min. respiration number. There was not any feature in her background and family history; there was no history of taking medication. Her cardiovascular system examination was normal. The patient's general condition was good. She was conscious and cooperative in her neurological examination. She did not have meningeal irritation findings and pathological reflexes. In her skin examination there were a large number of red-brown maculopapular erythemas. The patient was first started replacement with isotonic liquid treatment and paracetamol PO was given. Leucocyte was found to be $6.999 / \mathrm{mm}^{3}$ ( $83.7 \%$ neutrophile), platelet to be $154,000 / \mathrm{mm}^{3}$ in blood cell count, and in biochemical profile liver enzymes were found to be ASO $114 \mathrm{IU} / \mathrm{ml}$, RF $13 \mathrm{IU} / \mathrm{ml}$ (AST $32 \mathrm{U} / \mathrm{L}$, ALT 51U/L, ALP $61 \mathrm{U} / \mathrm{L}$, LDH $103 \mathrm{mg} / \mathrm{dl}$ ), and kidney functions test were found to be CRP $136.4 \mathrm{mg} / \mathrm{L}$ (urea $22 \mathrm{mg} / \mathrm{dl}$, creatinine $0.6 \mathrm{mg} / \mathrm{dl}$ ). Sedimentation was found to be $23 \mathrm{~mm} / \mathrm{h}$; Grubel Widal (Plasmatec, Turkey), Rose Bengal (Seromed, Turkey) and ANA (Euroimmun, US) test result were found to be negative; HBsAg, anti-HBc IgM, anti-HCV were found to be negative and anti-HBs (Roche Analytics E170 Immunology Analyzer, Germany) were found to be positive. Although tick bite history was not mentioned in the anamnesis of the patient, serologic tests were required by considering that the patients clinic could be in compliance with Lyme disease. With the help of ELISA method (Novatec, Germany) B. burgdorferi IgM was found to be $23.9 \mathrm{AU} / \mathrm{ml}$ positive, IgG to be negative. The patient whose Lyme disease diagnosis was supported serologically was started doxicycline $2 \times 100 \mathrm{mg} /$ day PO (3 weeks) and prenisolon $16 \mathrm{mg} /$ day (reducing the dose, 4 weeks). On the second day of the treatment arthralgia got remarkable decreased. During the follow ups, color on the lesions on the skin got pale, and remarkable decrease was observed, any systemic findings were not encountered. Her joint complaints got completely better in the control three months later.

Enlightened written approval was taken from the patient about the fact that information and photographs (Figure 1) about her illness can be used in this paper.

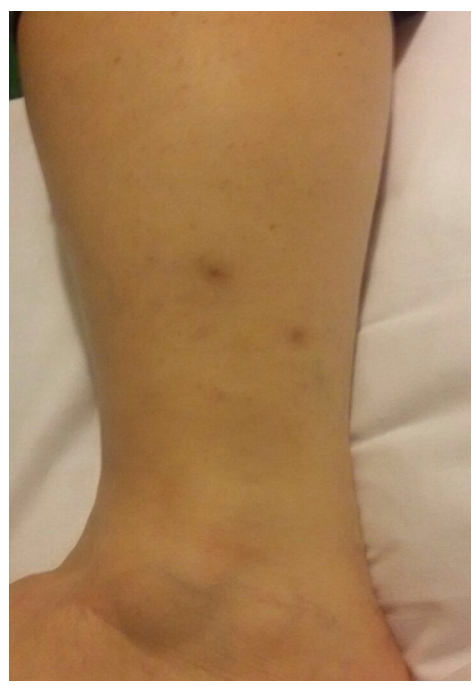

Figure 1. Erythematous lesions over left and right lower leg after treatment. 


\section{Discussion}

LD causes involvement in many systems such as skin, joints, heart and central nervous system. Symptoms of infection are erythema migrans, arthritis, facial palsy, radiculoneuropathy, artythmia and meningitis [24]. It is a zoonose that can cause chronic inflammatory response with its complications that appear in the late-term. There is high success in the cases treated with antibiotics but cases with severe prognosis were rarely reported [25]. The first Lyme cases and isolation of the factor from the vectoring tick types started to be reported after 1990 [26].

In an epidemiological research studying on the cases in 2005-2010 in the USA, it was reported that it was more frequently observed especially in the northern and eastern states of American continent and in summer months, type of the tick was I. scapularis, average age was 37, and 51.9\% of the cases were females, and the total number of cases was 45.430 [8]. In Turkey in rural areas the seroprevalence of $B$. burgdorferi was reported to be $36 \%$ but the number of cases diagnosed with Lyme disease is quite low [27] [28]. When B. burgdorferi was examined in the patients diagnosed with morphea and lichen sclerosus in dermatology clinics, it was found to be positive by $30 \%$ and $50 \%$, respectively [29] [30]. The vector tick type was reported to be I.ricinus in Marmara and Blacksea regions in Turkey [31]. In this study, B. burgdorferi sensu strict, B. garinii, B. afzelii, B. valasiana, $B$. lusitaniae were reported to be carried with this type of ticks. Spirochete genomes in Turkey were sequenced and were found to show high similarity (97\% - 100\%) to its European origins [32].

Anti-Borrelia antibodies are thought to be common in the risk group especially in Mediterranean and Marmara regions. There are studies from different regions about seropositivity rates (6\% - 44\%) [33]. Mutlu et al. [34] found seropositivity by $19 \%$ - 44\% in risky group and $2 \%$ - 6\% in low risk group; Gökfidan [35] found seropositivity by $26 \%$ in Adana district; Aydın et al. [36] found seropositivity by $6.6 \%$ in both risk group and low risk group equally in Blacksea Region; Tünger and Büke [37] found seropositivity by $7.8 \%$ in mountaineous villages of İzmir district; Erensoy [38] found seropositivity by $6 \%$ in the risk group of Elazığ district; Göral et al. [39] found seropositivity by $35.8 \%$ in the risk group and by $1.4 \%$ in the non-risk group of around Bilecik.

The first target in prevention of LD is preventing tick bites. Some of the precautions to be taken are wearing light colored clothing, keeping long pants tucked into socks and using repellant such as diethyl-3-methylbenzamide and picaridin [40] [41]. Current studies suggest that repellents may be natural, made from eucalyptus, tomato and coconut, or synthetic, among which the most widely used is DEET (N,N,-Diethyl-m-toluamide). Synthetic repellents are less toxic, also exhibit greater efficacy against ticks such as IR3535 [42].

On the dogs living in the regions where LD is endemic, no findings are observed but high positivity is detected in the antibodies test [43]. There are Lyme vaccinations available for animals. It is possible to protect dogs from Borrelia types that can be transmitted from ticks through vaccination at an early term [44].

\section{Conclusion}

It is necessary for physicians to perform physical examination carefully, at full detail and with a systemic approach in emergency services with wide patient spectrum and in primary care health institutions. Tick-originated diseases can be encountered especially in those living in rural areas and those visiting such kind of places. LD, one of the frequent diseases among these, can cause severe sequelae by affecting many organs if not treated. Therefore, early diagnosis and treatment is very important. This is vitally important for cases having applied especially with fever and erythema, having joint findings and general condition disorders and impaired consciousness.

\section{References}

[1] Stere, A.C., Coburn, J. and Glickstein, L. (2004) The Emergence of Lymedisease. Journal of Clinical Investigation, 113, 1093-1101. http://dx.doi.org/10.1172/JCI21681

[2] Baranton, G., Postic, D., Saint Girons, I., Boerlin, P., Piffaretti, J.-C., Assous, M. and Grimont, P.A.D. (1992) Delineation of Borrelia burgdorferi Sensu Stricto, Borrelia garinii sp. nov., and Group VS461 Associated with Lyme Borreliosis. International Journal of Systematic Bacteriology, 42, 378-383.

http://dx.doi.org/10.1099/00207713-42-3-378

[3] Canica, M.M., Nato, F., du Merle, L., Mazie, J.C., Baranton, G. and Postic, D. (1993) Monoclonal Antibodies for İdentification of Borrelia afzelii sp. nov. Associated with late Cutaneous Manifestations of Lyme Borreliosis. Scandinavian Journal of Infectious Diseases, 25, 441-448. http://dx.doi.org/10.3109/00365549309008525 
[4] Postic, D., Assous, M.V., Grimont, P.A.D. and Baranton, G. (1994) Diversity of Borrelia Burgdorferi Sensu Lato Evidenced by Restriction Fragment Length Polymorphism of rrf (5S)-rrl (23S) İntergenic Spacer Amplicons. International Journal of Systematic Bacteriology, 44, 743-752. http://dx.doi.org/10.1099/00207713-44-4-743

[5] Crowder, C.D., Matthews, H.E., Schutzer, S., Rounds, M.A., Luft, B.J., Nolte, O., Campbell, S.R., Phillipson, C.A., Li, F., Sampath, R., et al. (2010) Genotypic Variation and Mixtures of Lyme Borrelia in Ixodes Ticks from North America and Europe. PLOS ONE, 14, e10650. http://dx.doi.org/10.1371/journal.pone.0010650

[6] Kugeler, K.J., Farley, G.M., Forrester, J.D. and Mead, P.S. (2015) Geographic Distribution and Expansion of Human Lyme Disease, United States. Emerging Infectious Diseases, 21, 1455-1457. http://dx.doi.org/10.3201/eid2108.141878

[7] Derviş, E. (2009) Ticks and Dermathology.Türkderm, 43, 132-138.

[8] National Notifiable Diseases Surveillance System (NNDSS) (2016) Lyme Disease (Borrelia burgdorferi). Case Definitions. http://www.cdc.gov/nndss/script/conditionsummary.aspx?CondID=100

[9] Cameron, D.J., Johnson, L.B. and Maloney, E.L. (2014) Evidence Assessments and Guideline Recommendations in Lyme Disease: The Clinical Management of Known Tick Bites, Erythema Migrans Rashes and Persistent Disease. Expert Review of Anti-Infective Therapy,12, 1103-1135. http://dx.doi.org/10.1586/14787210.2014.940900

[10] Mahalingam, M., Bhawan, J., Chomat, A.-M. and Hu, L. (2008) Lyme Borreliosis. Fitzpatrick’s Dermatology in General Medicine, Wolff, K., Goldsmith, L.A., Katz, S.I., Gilchrest, B.A., Paller, A.S. and Leffel, D.J., Eds., 7th Edition, McGraw Hill, New York, 1797-1806.

[11] Donta, S.T. (2012) Issues in the Diagnosis and Treatment of Lyme Disease. The Open Neurology Journal, 6, $140-145$. http://dx.doi.org/10.2174/1874205X01206010140

[12] Nelson, C.A., Starr, J.A., Kugeler, K.J. and Mead, P.S. (2016) Lyme Disease in Hispanics, United States, $2000-2013$. Emerging Infectious Diseases, 22, 522-525. http://dx.doi.org/10.3201/eid2203.151273

[13] Smith, B.G., Cruz Jr., A.I., Milewski, M.D. and Shapiro, E.D. (2011) Lyme Disease and the Orthopaedic Implications of Lyme Arthritis. Journal of the American Academy of Orthopaedic Surgeons, 19, 91-100. http://dx.doi.org/10.5435/00124635-201102000-00004

[14] Balcer, L.J., Winterkorn, J.M. and Galeta, S.L. (1997) Neuro-Ophthalmic Manifestations of Lyme Disease. Journal of Neuro-Ophthalmology, 17, 108-121. http://dx.doi.org/10.1097/00041327-199706000-00008

[15] Ang, C.W., Brandenburg, A.H., van Burgel, N.D., Bijlmer, H.A., Herremans, T. and Stelma, F. (2015) A Dutch Nationwide Evaluation of Serological Assays for Detection of Borrelia Antibodies in Clinically Well-Defined Patients on Behalf of the Dutch Working Group on Diagnosis of Lyme Borreliosis, Brandenburg. Diagnostic Microbiology and Infectious Disease, 83, 222-228. http://dx.doi.org/10.1016/j.diagmicrobio.2015.07.007

[16] Leeflang, M.M., Ang, C.W., Berkhout, J., Bijlmer, H.A., Van Bortel, W., Brandenburg, A.H., et al. (2016) The Diagnostic Accuracy of Serological Tests for Lyme Borreliosis in Europe: A Systematic Review and Meta-Analysis. BMC Infectious Diseases, 16, 140. http://dx.doi.org/10.1186/s12879-016-1468-4

[17] Jones, K.L., McHugh, G.A., Glickstein, L.J. and Stere, A.C. (2009) Analysis of Borrelia burgdorferi Genotypes in Patients with Lyme Arthritis: High Frequency of Ribosomal RNA Intergenic Spacer Type 1 Strains in AntibioticRefractory Arthritis. Arthritis \& Rheumatism, 60, 2174-2182. http://dx.doi.org/10.1002/art.24812

[18] Polat, E., Turhan, V., Aslan, M., Müsellim, B., Onem, Y. and Ertuğrul, B. (2010) First Report of Three Culture Confirmed Human Lyme Cases in Turkey. Mikrobiyoloji Bulteni, 44, 133-139.

[19] Melo, I.S., Gadelha, A.R. and Ferreira, L.C. (2003) Estudo histopatológico de casos de eritema crônico migratório diagnosticados em Manaus. Anais Brasileiros de Dermatologia, 78, 169-177. http://dx.doi.org/10.1590/s0365-05962003000200004

[20] Barsic, B., Maretic, T., Majerus, L. and Strugar, J. (2000) Comparison of Azithromycin and Doxycycline in the Treatment of Erythema Migrans. Infection, 28, 153-156. http://dx.doi.org/10.1007/s150100050069

[21] Institute of Medicine (US) Committee on Lyme Disease and Other Tick-Borne Diseases: The State of the Science (2011) Critical Needs and Gaps in Understanding Prevention, Amelioration, and Resolution of Lyme and Other TickBorne Diseases: The Short-Term and Long-Term Outcomes: Workshop Report. National Academies Press, Washington DC.

[22] Claerebout, E., Losson, B., Cochez, C., Casaert, S., Dalemans, A.C., De Cat, A., et al. (2013) Ticks and Associated Pathogens Collected from Dogs and Cats in Belgium. Parasites \& Vectors, 6, 183. http://dx.doi.org/10.1186/1756-3305-6-183

[23] Maia, C., Almeida, B., Coimbra, M., Fernandes, M.C., Cristóvão, J.M., Ramos, C., et al. (2015) Bacterial and Protozoal Agents of Canine Vector-Borne Diseases in the Blood of Domestic and Straydogs from Southern Portugal. Parasites \& Vectors, 8, 138. http://dx.doi.org/10.1186/s13071-015-0759-8

[24] Oliveira, C.R. and Shapiro, E.D. (2015) Update on Persistent Symptoms Associated with Lyme Disease. Current Opinion in Pediatrics, 27, 100-104. http://dx.doi.org/10.1097/MOP.0000000000000167 
[25] Vazquez, M., Sparrow, S.S. and Shapiro, E.D. (2003) Long-Term Neuropsychologic and Health Outcomes of Children with Facial Nerve Palsy Attributable to Lyme Disease. Pediatrics, 112, e93-e97. http://dx.doi.org/10.1542/peds.112.2.e93

[26] Sigal, L.H. (1990) Summary of the First 100 Patients Seen at a Lyme Disease Referral Center. The American Journal of Medicine, 88, 577-581. http://dx.doi.org/10.1016/0002-9343(90)90520-N

[27] Tuncer, D., Ogunc, D., Colak, D., Ongut, G., Sayin, F., Ergin, C., et al. (2000) Prevalence of Borrelia burgdorferi Antibodies in Urban and High Risk Areas of Turkey. Information Circular-WHO Mediterranean. Zoonoses Control Centre, 49, 8-9.

[28] Tunger, O. and Buke, M. (1995) Lyme Disease: Status in Izmir Region. Turkish Journal of Infection, 9, 345-349.

[29] Weide, B., Walz, T. and Garbe, C. (2000) Is Morphoea Caused by Borrelia burgdorferi? British Journal of Dermatology, 142, 636-644. http://dx.doi.org/10.1046/j.1365-2133.2000.03407.x

[30] Eisendle, K. and Zelger, B. (2009) The Expanding Spectrum of Cutaneous Borreliosis. Giornale Italiano di Dermatologia e Venereologia, 144, 157-171.

[31] Şen, E. (2006) Epidemiology of Lyme Disease. Türk Mikrobiyoloji Cemiyeti Dergisi, 36, 55-66.

[32] Șen, G.E. (2003) First Isolation and Characterization of B. burgdorferi Sensu Lato Strains from I. ricinus Ticks in Turkey. Journal of Medical Microbiology, 52, 807-813. http://dx.doi.org/10.1099/jmm.0.05205-0

[33] Doğanc1, L. (2008) Lyme Disease. In: Topçu, A.W., Söyletir, G. and Doğanay, M., Eds., Infection Disease and Microbiology, 3rd Edition, Nobel Medical Publishers, Istanbul, 973-988.

[34] Mutlu, G., Gültekin, M., Ergin, Ç., Sayın, F. and Kurşun, A.E. (1995) Investigation of Borrelia burgdorferi Antibodies and Vectors in Antalya Region. Mikrobiyoloji Bulteni, 29, 1-6.

[35] Gökfidan, S. (1992) Investigation of Prevalence B.burgdorferi with ELISA and IHA in Asemptomatic Population and Who Have Arthritis in Osmaniye Region. PhD Thesis, Çukurova University, Adana.

[36] Aydın, K. (1992) Lyme Seropositivity in Trabzon Region. XXVII Turkish Microbiology Congress.

[37] Tünger, Ö. and Büke, M. (1995) Lyme Disease in Izmir. National Infection Disease Congress.

[38] Erensoy, A. (1996) Investigation of Lyme Disease in Elazı̆̆ Region. XXVII Turkish Microbiology Congress.

[39] Göral, G., Kılıçturgay, K. and Aydın, L. (1997) Antibody Prevalance against B.burgdorferi in Some Villages in the Province of Bilecik. Turkish Journal of Medical Sciences, 27, 51-53.

[40] Pretorius, A.M., Jensenius, M., Clarke, F. and Ringertz, S.H. (2003) Repellent Efficacy of DEET and KBR 3023 against Amblyomma hebraeum (Acari: Ixodidae). Journal of Medical Entomology, 40, 245-248. http://dx.doi.org/10.1603/0022-2585-40.2.245

[41] Clark, R.P. and Hu, L.T. (2008) Prevention of Lyme Disease and Other Tick Borne Infections. Infectious Disease Clinics of North America, 22, 381-396. http://dx.doi.org/10.1016/j.idc.2008.03.007

[42] Boulanger, N. and Lipsker, D. (2015) Protection against Tick Bites. Annales de Dermatologie et de Vénéréologie, 142, 245-251. http://dx.doi.org/10.1016/j.annder.2014.11.018

[43] Gauthier, D.T. and Mansfield, L.S. (1999) Western Immunoblot Analysis for Distinguishing Vaccination and Infection Status with Borrelia burgdorferi (Lyme Disease) in Dogs. Journal of Veterinary Diagnostic Investigation, 11, $259-265$. http://dx.doi.org/10.1177/104063879901100309

[44] Tsao, K., Fish, D. and Galvani, A.P. (2012) Predicted Outcomes of Vaccinating Wildlife to Reduce Human Risk of Lyme Disease. Vector-Borne and Zoonotic Diseases, 12, 544-551. http://dx.doi.org/10.1089/vbz.2011.0731 